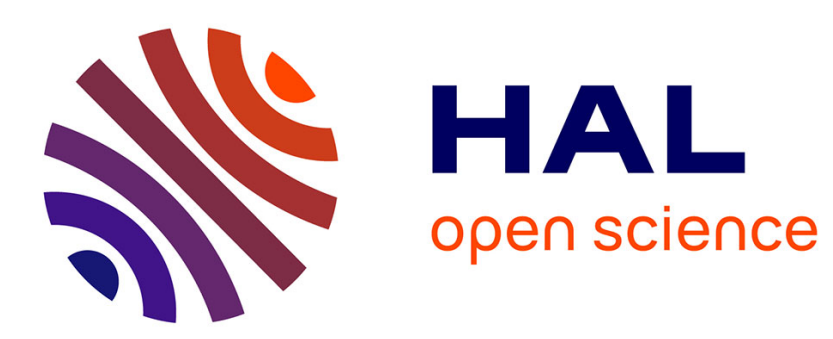

\title{
The effect of sea shore displacement on population age structure of coastal Alnus glutinosa (L.) Gaertn. \\ Wolfgang Cramer
}

\section{To cite this version:}

Wolfgang Cramer. The effect of sea shore displacement on population age structure of coastal Alnus glutinosa (L.) Gaertn.. Ecography, 1985, 8 (4), pp.265 - 272. 10.1111/j.1600-0587.1985.tb01178.x . hal-01758327

\section{HAL Id: hal-01758327 \\ https://hal.science/hal-01758327}

Submitted on 10 Apr 2018

HAL is a multi-disciplinary open access archive for the deposit and dissemination of scientific research documents, whether they are published or not. The documents may come from teaching and research institutions in France or abroad, or from public or private research centers.
L'archive ouverte pluridisciplinaire HAL, est destinée au dépôt et à la diffusion de documents scientifiques de niveau recherche, publiés ou non, émanant des établissements d'enseignement et de recherche français ou étrangers, des laboratoires publics ou privés. 


\title{
The effect of sea shore displacement on population age structure of coastal Alnus glutinosa (L.) Gaertn.
}

\author{
Wolfgang Cramer
}

\begin{abstract}
The age structure of Alnus glutinosa (L.) Gaertn. populations was studied in two areas on the coast of the Baltic Sea. One area, situated in Uppland, eastern central Sweden, at 60$)^{\circ} 07^{\prime} \mathrm{N}$, has a relative land uplift of $5.3 \mathrm{~mm}$ yr '; the other area, situated in Blekinge, southeastern Sweden, at $56^{\circ} 10^{\prime} \mathrm{N}$, is nearly stable. The spatial distribu-tion of 200 Alnus individuals of various age classes at nine sites was analyzed in order to reconstruct establishment history. In the land uplift area, the youngest individuals were found in the lowest parts of the sites, and age and elevation were significantly correlated. In the area without land uplift, no such pattern was found. Regression analysis of the time/space pattern of establishment in the land uplift area showed that the zone where individuals establish follows the moving shore line with roughly con-stant speed. Alnus glutinosa uses two different regenerative strategies: (1) continuous colonization of emerging land from seeds (with subsequent mortality of the older trees) in the land uplift area, and (2) regeneration from old stem bases, formıng mul-tistemmed trees, in the area without land uplift.
\end{abstract}

W. Cramer, Institute of Ecological Botany, Uppsala University, P.O. Box 559, S-751 22 Uppsala, Sweden.

\section{Introduction}

\subsection{Sea shore displacement and vegetation succession}

Postglacial isostatic land uplift causes considerable sea shore displacement on the coasts of the central and northern Baltic. While new land emerges from the sea, formerly wave-washed shore areas undergo drastic environmental changes. At sheltered sites, accumulation of lacustrine mineral and organogenic sediments contribute to a gradual development from aquatic to terrestrial conditions in a few hundreds of years. At more exposed sites, erosion may delay the process of sea shore displacement. Here the substratum is modified to a coarser texture, or eroded to bare rock. Heavy ice-push can occur and accelerate or stop sea shore displacement on all shore types. Sea shore displacement is the sum of land uplift and all geomorphic processes changing the shore line.
The first vascular plants colonizing rising shores of the Baltic are comparatively short-lived herbs establishing over large areas in low water years. They are often damaged or removed in the following winters or high water periods. Colonization on such shores has been described as a 'step-by-step process', i.e. a process governed by a sequential set of prerequisites that are to be fulfilled if lasting establishment of a plant shall take place (Ericson 1980).

The most common woody species of the geolittoral (i.e. the area between maximum high water level and mean water level) on shores of the central Baltic that are not disturbed by humans are Alnus glutinosa L. (Gaertn.)* (on sheltered shores) and Hippophae rhamnoides L. (on exposed shores). Other woody species growing in the geolittoral are Sorbus aucuparia L. and

- Nomenclature follows Lid (1974). 
Fraxinus excelsior L. In this study, interest is focused upon the relation between sea shore displacement and the establishment of Alnus glutinosa, a long-lived woody species establishing mainly from seeds. Hippophae rhamnoides, in contrast, is a predominantly clonal species; comparable results for Hippophae will be presented in a later paper.

With a relative land uplift (in relation to mean sea level) of more than $5 \mathrm{~mm} \mathrm{yr}^{-1}$, individuals of woody species growing in the geolittoral experience a considerable change of environment during their life-span. Inundation periods decrease in length and frequency, and soil moisture consequently decreases. The age structure of Alnus glutinosa populations might be expected to reflect this change.

Alnus glutinosa colonizes the geolittoral in the land uplift areas exclusively by establishment from seeds that are shed in sufficient amounts every winter (McVean 1955a). Vegetative propagation is observed only on the remnants of old, damaged, or rotten stem bases, which then often form a multistemmed tree.

To study the role of Alnus glutinosa in succession after sea shore displacement, I compared stands on the shores of Uppland (central Sweden) and Blekinge (south Sweden). The former area has a land uplift of

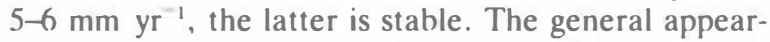
ance of the vegetation zonation (Alnus glutinosa woodland facing a sea shore meadow or another type of herbdominated vegetation on sheltered shores) is the same in both areas, though the floristic composition of the field layer varies.

\subsection{Population dynamics of survivors - the limits of age structure analysis}

The population dynamics of long-lived species can be studied indirectly by analysis of age structure. This technique yields information only about the surviving individuals, their survivorship rates remain hidden. Nevertheless, the interpretation of age structure diagrams can give ideas about the past development of populations. For example, the spatial distribution of different ageclasses can give indirect information on recent environmental history (Maarel et al. 1984). Being 'critical for understanding succession' (Peet and Christensen 1980), establishment of trees in the past and present can be studied with the use of age structure analysis. A discussion of population dynamics on the basis of age structure diagrams must necessarily be built on assumptions about the recruitment and mortality of the population studied (Harper 1977). In the case of Alnus glutinosa, the general knowledge about these variables is excellent (McVean 1953, 1955a, b, 1956a, b, c, d, 1959, Trappe et al. 1968, Fremstad 1983).

\section{Study areas}

\section{I. The study area with land uplin}

The nature reserve 'Häverö Prästäng' is situated at $60^{\circ} 07^{\prime} \mathrm{N}, 18^{\circ} 42^{\prime} \mathrm{E}$ on the coast of Uppland, eastern central Sweden. It is a peninsula in a relatively sheltcred part of the archipelago, offering a variety of shore types - from north-exposed rocky shores to morainic shores with meadow vegetation and sheltered Phragmites communis Trin. stands.

At Häverö Prästäng, relative land uplift at present

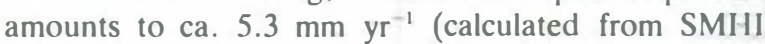
1976). Because of mineral and organogenic sedimentation (shore drift and plant necromass accumulation, respectively) in the Phragmites communis zone, the sheltered shores can have an even faster displacement than would follow from the simple addition of slope and relative uplift. An estimate of the total shore displacement in the nature reserve has been obtained from comparison of maps from different times, presented in an earlier paper (Cramer 198()).

There are considerable differences in the vegetation of different geomorphic shore types in the area (Cramer 1981). Rocky shores with big boulders carry a sparse vegetation with a few graminoids (Phalaris arundinacea L., Agrostis stolonifera L.) in the lower geolittoral. Higher up, some Hippophae rhamnoides bushes form an edge to woodlands and forests of varying composition, commonly including Alnus glutinosa, Fraxinus excelsior, and Sorbus intermedia (Ehrh.) Pers.

Slightly more sheltered shores have a denser herb vegetation beginning close to mean water level with Scirpus tabernaemontani C. C. Gmel., then Aster tripolium L., Triglochin maritimum L., and other salt-tolerating species in the geolittoral. Above this level, the densest Hippophae thickets are found. Still higher up these are replaced by Alnus glutinosa-stands, which, in turn, are followed by woodlands of Fraxinus excelsior and Populus tremula L.

The strongly sheltered shores have extensive reeds of Phragmites communis in a wide range of the hydro- and geolittoral, followed by a dense meadow completely dominated by Juncus gerardii Lois. Hippophae rhamnoides is rare; more often Alnus glutinosa forms the next belt with large, well developed stands with a closed canopy containing few other tree species, mainly Populus tremula and Acer platanoides L. At higher elevations, Alnus stems are found dying, and no new sprouts are visible on their bases. Here other trees such as Fraxinus excelsior and Populus tremula establish. At still higher elevations (6-10) $\mathrm{m}$ above sea level) a dense Picea abies (L.) Karst. forest can develop.

\subsection{The study area without land uplift}

I searched the surroundings of the city of Karlskrona, Blekinge, southern Sweden, in order to find a relatively undisturbed area for comparison with the results from 
field work in Uppland. I chose the extensive stands of Alrus glutinosa on the innermost western shores of Hallarumsviken, a bay on $56^{\circ} 10^{\prime} \mathrm{N}, 15^{\circ} 49^{\prime} \mathrm{E}$, about $14 \mathrm{~km}$ east of Karlskrona for this study.

The coast of Blekinge has a relative land uplift of only ().3 $\mathrm{mm} \mathrm{yr}^{-1}$ (SMHI 1976). The area is therefore geomorphically stable on a time-scale significant to plant populations. On the other hand, during historic and prehistoric times, the Baltic underwent big changes in sea level. It is difficult to estimate the length of the period with about the same water level conditions as today. For the time since $2000 \mathrm{BP}$, no evidence for major sea level fluctuations exceeding the uplift of $0.3-0.4 \mathrm{~mm}$ $\mathrm{yr}^{-1}$ could be found (Berglund 1964). For this study, I have assumed that the water level regime has been stable for at least a few hundred years.

The substrate of the shore studied in Blekinge is a stratified sandy/clayey matcrial indicating that sedimentation (mainly in the Phragmites reeds) has occurred until recently. Therefore, som shore displacement towards the sea has to be taken into account, although far less than in Uppland, and with only marginal significance for the woodlands nearby.

The sheltered shores of Hallarumsviken have dense Phragmites communis reeds, tens of metres wide. Inland, there is a gradual decrease of Phragmites communis cover into a belt with Scirpus maritimus L. and Agrostis stolonifera, which is replaced then by a community dominated by Juncus articulatus L., Hydrocotyle vulgaris $\mathrm{L}$... and Lycopus europaeus L. This belt has a distinct border towards the Alnus glutinosa stands. These woodlands generally contain few other tree species and their field layer is dominated by Lycopus europaeus and Filipendula ulmaria (L.) Maxim. At other sites, the canopy includes Betula verrucosa Ehrh., Rhammus frangula L., and Lonicera periclymenum L., and the field layer includes Viola palustris L., Stellaria media (L.) Vill., and several ferns (Athyrium filix-femina (L.) Roth., Pteridium aquilinum (L.) Kuhn).

\section{Methods}

\subsection{Age structure analysis}

Seven Almus glutinosa stands were chosen for age structure analysis: 5 in Uppland and 2 in Blekinge. The major selection criterion was the absence of significant human disturbances. This point was checked through field observation, and by interviewing persons responsible for the management of areas nearby. Two additional sites were investigated (one in Uppland and one in Blekinge) representing stands with high dominance of tree species other than Alnus glutinosa. Data from these additional sites were included for some statistical treatments.

A sample of the central part of each stand, including 20) to 46 individual trees, was analyzed by
- mapping each tree's position, and noting general features of the surrounding vegetation units (forest, meadow, etc.)

- taking an increment core of each stem inside the plot

- levelling each tree in relation to zero level in the Swedish geodetic system

- measuring each tree's height, diameter at base, and diameter at breast height.

The trees were bored with a standard increment borer. The core was taken as close to the stem base as possible - usually at ca. 1(l-15 cm above ground. The first core that hit the centre of the stem was used. The cores were cut with a razorblade perpendicular to the vessels and the rings were counted under a stereo-microscope. The annual rings of Almus glurinosa are comparatively difficult to recognize, and the stems are often asymmetrical close to the ground, thus making the centre difficult to hit and creating zones with narrow rings. Many young trees suffer damage on the side exposed to the seit caused by ice-movements (Wikström 1966). For this reason, I avoided making borings on the exposed side of the trees. The smallest trees in the plots could not be bored. Age determination by counting of terminal bud scars seemed not to be appropriate for most of them, because many showed damage from ice-pressure. I therefore cut them and counted their annual rings.

For the present study, I have assumed that (1) ring counts give a sufficiently accurate estimate of age, and (2) age may be slightly higher than the number of annual rings counted, because rings are sometimes incomplete or missing and the height of the first or second year's sapling can be less than the height of the borer's position.

A special problem arose with the multistemmed $A$ / nus glutinosa trees that are abundant on the Blekinge sites. At least three of the thickest trunks of any of these individuals were bored in the manner described above. and the highest value obtained from such an individual was used for further treatments. It is probable that the genet of such individuals is much older than this value indicates.

The position of all trees was mapped on graph-paper. The trees were marked with running numbers, and they were levelled in relation to the Swedish geodetic system based on the year $19(x)$. For the Uppland material I added 82 times $(0.53 \mathrm{~cm}=43.5 \mathrm{~cm}$ to each value to take account of relative land uplift since the beginning of the century.

\subsection{Water level observations}

For Uppland, water level observations provided by the Swedish Meteorological Service were used from two mareographs: (1) Björn (about $72 \mathrm{~km}$ north of the study area) for 1922-1975 (because of land uplift, the station ceased to operate in 1975) and (2) Forsmark (about 4() $\mathrm{km}$ north of the study area) for 1976-1982. 
For Blekinge, observations were used of a mareograph at Kungsholmsfort (about $14 \mathrm{~km}$ west of the study area) for 1922-1982.

\subsection{Statistics}

All numerical data treatments were done on the CDC Cyber 174 at the computer centre of the University of Giessen (West Germany). The most recent version of the 'Statistical Package for the Social Sciences' (SPSS9, Beutel \& Schubö 1983) was used.

\section{Results}

\subsection{Age structure of single stands}

A common feature of the Alnus glutinosa stands studied is the absence of Alnus seedlings (cf. Fig. $1 \mathrm{~A}$ and B). A few saplings of $<10$ years of age were recorded, but all of these grew close to the edge between the woodland and the herb-dominated sea shore vegetation. The youngest tree in the Uppland material had 4 annual rings, and the minimum age per site varied between 4 and $11 \mathrm{yr}$; the youngest tree on either site in Blekinge had 16 annual rings.

A number of Alnus seedlings were observed in the herb-dominated sea shore vegetation outside the woods of the Uppland study area, but in Blekinge I found no Alnus seedlings in the sea shore vegetation next to the plots.

In the Uppland material, the maximum age per site varied between 36 and $78 \mathrm{yr}$, but several of the trees were rotten inside and could not be analyzed. I observed the same phenomenon in Blekinge; there the maximum age varied from 37 to $73 \mathrm{yr}$.

\subsection{Comparison of stands in the land uplift area - differences in the total range of elevation}

There are differences in elevation above sea level between the various plots in the land uplift area. The medians for this factor are given in Tab. 1 for five Uppland stands. The vertical position of biotic belts on a sea shore often rises with increasing exposure to the sea (DuRietz 1947); so this variation probably reflects the

Tab. 1. Median values for the elevation of Alnus glutinosa trees in the plots analyzed in Uppland. Values in $\mathrm{cm}$ above zero for 1982.

\begin{tabular}{|c|c|c|}
\hline Site & Median & No. of trees \\
\hline $\mathbf{A} \ldots \ldots \ldots \ldots \ldots \ldots \ldots$ & 24.5 & 43 \\
\hline $\mathrm{C} \ldots \ldots \ldots \ldots \ldots \ldots \ldots$ & 62.8 & 18 \\
\hline 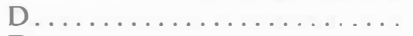 & 65.5 & 23 \\
\hline$E \ldots \ldots \ldots \ldots \ldots \ldots$ & 47.0 & 14 \\
\hline$F \ldots \ldots \ldots \ldots \ldots \ldots$ & 92.5 & 11 \\
\hline I. $\ldots \ldots \ldots \ldots \ldots \ldots$ & 48.5 & 21 \\
\hline
\end{tabular}

gradient in exposure to wave action and salt spray (Ericson 1972). Consequently, the total material from the area cannot be lumped into one data set; it is more useful to consider the data for each stand separately.

\subsection{The relation between elevation and age for each stand}

In the Uppland plots the older trees, in general, are spatially separated from the younger ones. The older trees are more abundant at higher elevations and the younger trees occur mostly at lower elevations. The Blekinge plots, on the other hand, do not show such a distribution. Trees of different ages are spread over the whole area. No agglomeration or trend is visible.

To display the differences in age structure between the lower and higher parts of each site, I separated each data set into subsets of equal size according to the ele-
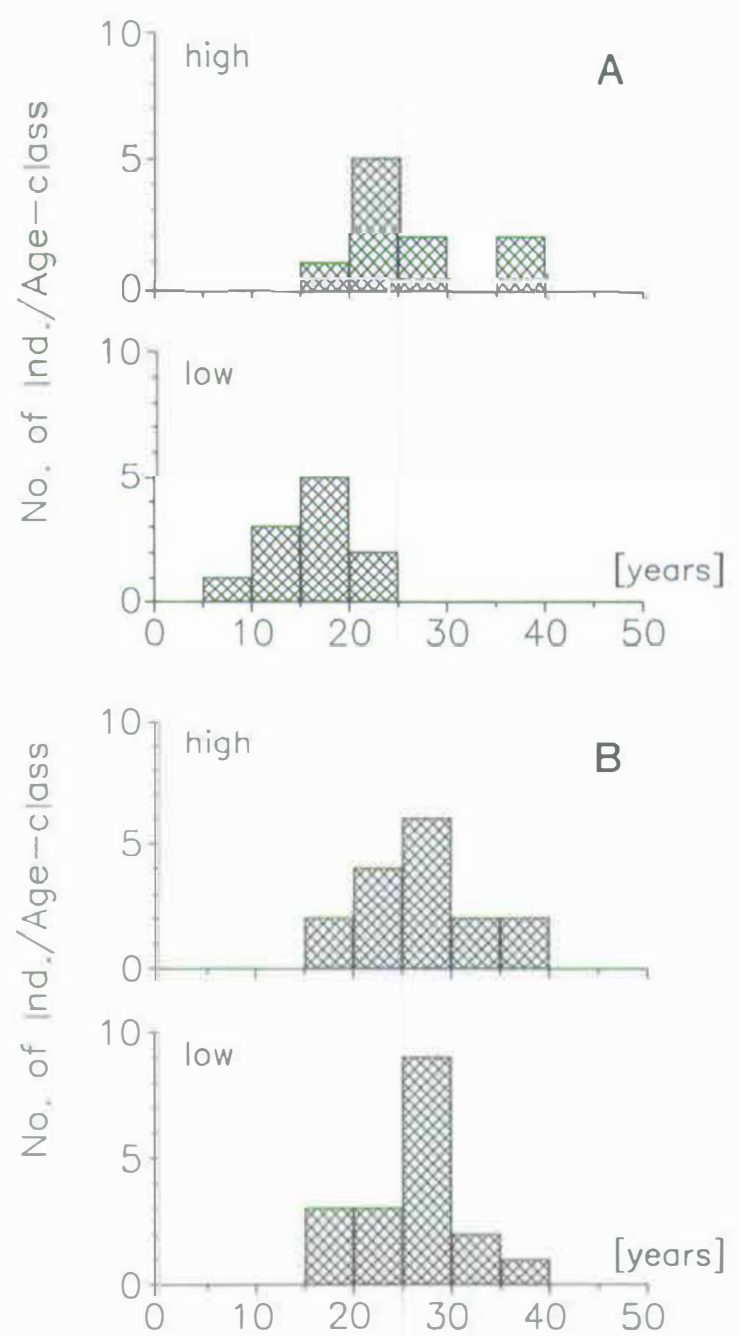

Fig. 1. Age-class distribution of Alnus glutinosa individuals in (A) plot I (land uplift area) and (B) plot G (area without land uplift), divided in two subsets of equal size, one in the upper part of the plot ('high') and one in the lower part ('low'). 


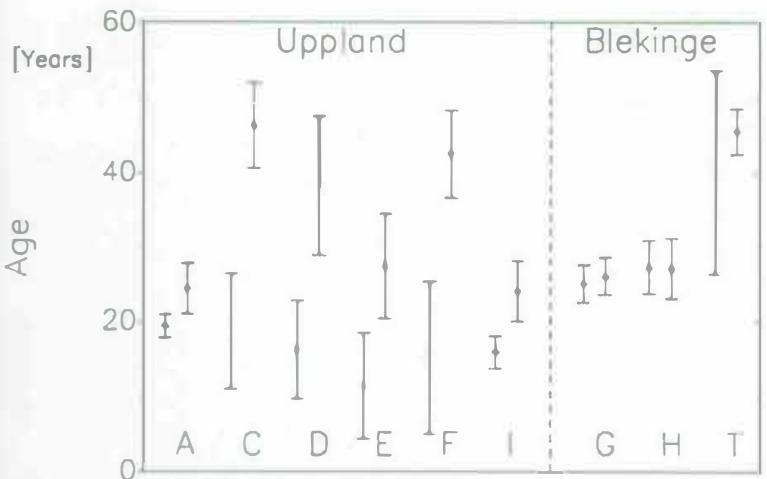

Fig. 2. Mean age of Alnus glutinosa individuals in 9 plots in Uppland and Blekinge (Central and South Sweden), each stand divided in two subsets of equal size, one for the upper part (right) and one for the lower part (left). The symbols indicate the mean value (years), the length of each bar gives the 95\%-confidence interval. Capital letters are plot codes, A, C. D, E, F, I (land uplift area) and G, H. T (area without land uplift).

vations of individual trees. These subsets were compared in two ways. First, I plotted age structure diagrams to give an impression of possible differences that could be tested statistically. Two such graphs are presented in Figs. IA and B for the plots I (Uppland) and $\mathrm{G}$ (Blekinge). Although the sample sizes for each of the diagrams are small, a clear difference can be seen: the low parts of the Uppland stands contain more young trees and fewer old trees than the high parts. The Blekinge material does not show any such trend. To test this observation for the whole material, I computed mean and $95 \%$-confidence interval for the number of annual rings in each subset (Fig. 2). The graph demonstrates that there are significant differences between the means of lower and higher elevation subsets for all sites from Uppland, but not in the Blekinge material.

To test whether the relation between elevation and age holds for the entire elevation range sampled, I computed Spearman rank correlation coefficients (Tab. 2). These showed that for all Uppland sites, elevation is correlated with age with a significance at $P<0.01$. The coefficients vary from (0.479 to 0.788 , and thus explain

Tah. 2. Spearman correlation coefficients between elevation and age for each Alnus glutinosa site (A-1: Uppland sites; $G$, H, T: Blekinge sites). ${ }^{* *} p<0.01,{ }^{* * *} p<0 .(0) 1$.

\begin{tabular}{|c|c|c|c|}
\hline Site & $\mathbf{r}$ & $r^{2}(\%)$ & $\mathrm{S}$ \\
\hline$A \ldots \ldots \ldots$ & 0.4798 & 23.0 & $(* * *)$ \\
\hline$C \ldots \ldots \ldots \ldots$ & 0.7887 & 62.2 & $(* * *)$ \\
\hline$D \ldots \ldots \ldots \ldots$ & 0.7468 & 55.8 & $(* * *)$ \\
\hline$E \ldots \ldots \ldots$ & 0.7203 & 51.9 & ()$\left.^{+}\right)$ \\
\hline $\bar{F} \ldots \ldots \ldots \ldots$ & 0.7545 & 56.9 & $(+\infty)$ \\
\hline$I \ldots \ldots \ldots \ldots$ & 0.6995 & 48.9 & $(* * *)$ \\
\hline G..... & 0.1964 & 3.9 & \\
\hline$H \ldots \ldots \ldots \ldots$ & 0.2822 & 8.0 & \\
\hline $\mathrm{T} \ldots \ldots \ldots$ & 0.3364 & 11.3 & \\
\hline
\end{tabular}

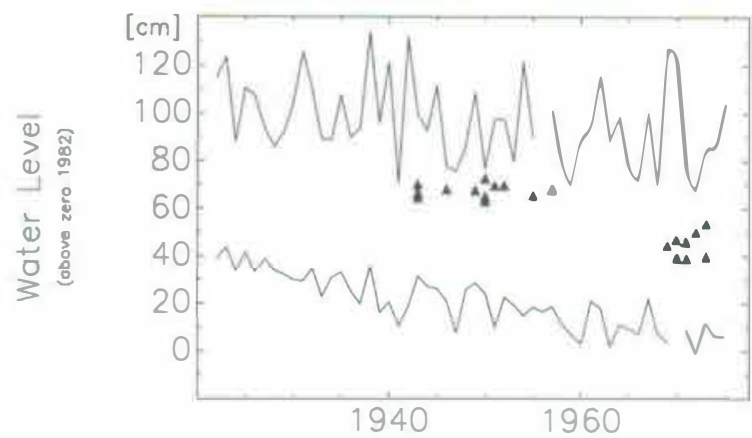

Fig. 3. Time-space locations of establishment of Alnus glutimosa individuals in plot D (land uplift area) compared with water level observations for the mareograph 'Björn' $(72 \mathrm{~km}$ north of the study area). The upper line gives the annual maximum water level, the lower line the annual mean water level. Both are related to 1982's zero level and cover the period 1922-1975.

between 23 and $62 \%$ of the total variance of age (= number of annual rings counted) with the factor elevation. By contrast, the Blekinge material shows no significant correlation $\left(P>0.05, r^{2}<12 \%\right)$ between Alnus age and elevation.

\subsection{The correlation between elevation and age compared with long term movements of water table}

To compare the long term movements of the water table with the vertical position of the establishment locations for the trees, I plotted a diagram that relates both variables to the same zero level (Fig. 3 is an example for site D). 'Year of establishment' is calculated here as 1982 minus no. of annual rings counted. Note that Alnus glutinosa establishes only in the geolittoral (below high water level and above mean water level).

To visualize the correlation between elevation and age in the Uppland material, I performed a linear regression analysis both for the point clouds of establishment locations and for the complete set of sea level data (Fig. 4 presents the results for the four plots C, D,

Tab. 3. Slopes (b) of the linear regression between elevation and age for all Alnus glutinosa sites with a significant Spearman correlation $(P<0.01)$ and their difference to the local rate of relative land uplift $\left(0.53 \mathrm{~mm} \mathrm{yr}^{-1}\right)$.

\begin{tabular}{|c|c|c|}
\hline Site & b & $\begin{array}{l}\text { Difference to uplift } \\
\text { rate }(P<0.05)\end{array}$ \\
\hline$\ldots \ldots \ldots \ldots \ldots$ & 1.0186 & sign. \\
\hline$\cdots$ & 0.7548 & not sign. \\
\hline$D \ldots \ldots \ldots \ldots \ldots$ & 0.9146 & sign. \\
\hline $\mathrm{E} \ldots \ldots \ldots \ldots \ldots$ & 0.7780 & not sign. \\
\hline 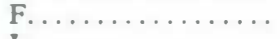 & 0.8065 & not sign. \\
\hline $1 \ldots \ldots \ldots \ldots \ldots$ & 1.0596 & sign. \\
\hline
\end{tabular}



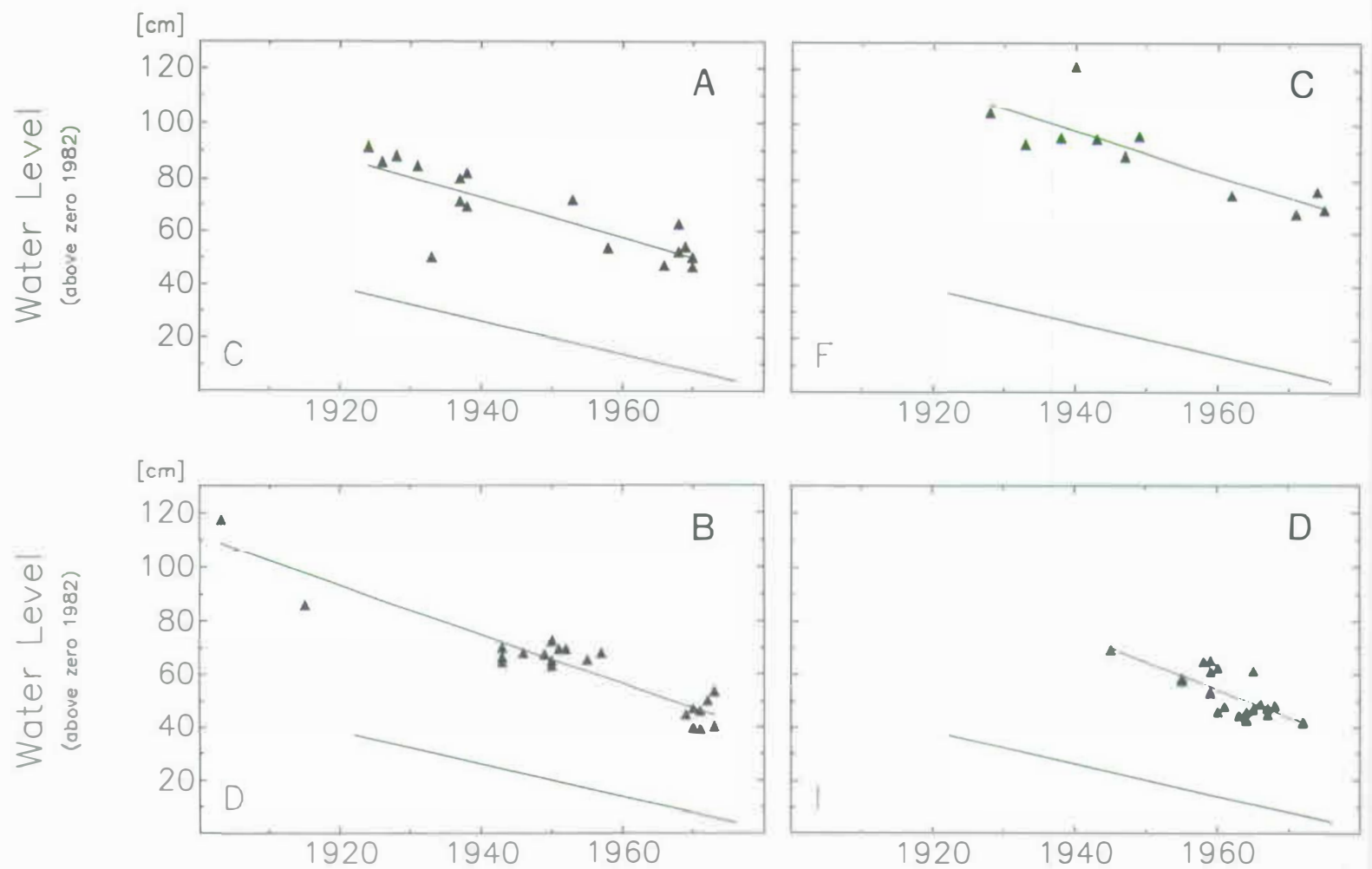

Fig. 4. Regression lines for the point clouds of time-space locations of Alnus glutinosa in 4 stands compared with relative land uplift (lower line). A: plot C, B: plot D, C: plot F, D: plot I.

$\mathrm{F}$, and I). The lower line indicates the relative lowering of sea level. The upper line represents the trend for the vertical movement of the location of establishment for Alnus glutinosa during time.

The slopes of these regression lines are given in Tab. 3. All regression lines calculated for the trees were slightly steeper than the line derived from the sea level data, but the graphs demonstrate that these differences are small compared with the period studied. For sites $C$. $E$, and $F$, the $95 \%$-confidence intervals for the slopes of the regression lines include the value for the local rate of land uplift $\left(0.53 \mathrm{~mm} \mathrm{yr}^{-1}\right)$, the other sites in the land uplift area have regression coefficients significantly higher than the land uplift rate. This difference can be seen in relation to the varying degree of exposure: sites $C, E$, and $F$ are situated on more exposed morainic shores, and sites $\mathrm{A}, \mathrm{D}$, and $\mathrm{I}$ are all in sheltered bays with recent sedimentation. The downward trend of the establishment zone has 'tracked' the downward trend in relative sea level, and the slope of this trend is related to the degree of exposure.

\section{Discussion}

In the land uplift area, age structure analysis of the stands demonstrated the distribution of establishing individuals of Almus glutinosa during different periods. As age increased with elevation (cf. Tabs 2 and 3), the dis- placement of the zone with successfully establishing plants could be shown to be similar to sea shore displacement.

The absence of Alnus-seedlings below the canopy of mature Almus trees agrees with statements in the literature (Kujala 1924, McVean 1953, 1955b, 1956a, Schalin 1967, 1968, Ruth 1968, Maarel et al. 1984). Several causes for this absence have been suggested, including intolerance of shading (McVean 1953, 1956a, Ruth 1968), root competition (Kujala 1924), allelopathic effects, such as inhibition of germination by Alnus twig. leaf or catkin particles in the top soil layer (McVean 1955b), and absence of mineral soil required for germination (for $A$. incana (L.) Moench: Schalin 1967, 1968).

The position of Almus glutinosa-trees on the edge between forest and sea shore in the land uplift area can be viewed in two different contexts: (1) the static 'zonation' view, explaining the occurrence of the species only by its requirements concerning the soil moisture gradient, and (2) the dynamic successional view, describing the role of Almus in terms of the (Clementsian) 'facilitation model' (Connell and Slatyer 1977), whereby the moisture-tolerant nitrogen fixing $A$ lnus-trees 'prepare the ground' for other woody species demanding a higher resource level and replacing them at higher elevations. To explain the role of Alnus glutinosa in succession more fully, we require a niche concept that covers both the habitat requirements and the functional role of a 
species in the community. Grubb (1977) pointed out that the presence of a species in a steady state community can only be maintained if a distinct 'regeneration niche' exists. Grubb's concept could be extended hy defining an 'establishment niche', an expression of all the requirements for a high chance of establishment of a plant diaspore. It is that part of the total niche hyperspace which is determined by biotic and abiotic factors that are important for establishment. The establishment niche is a formalization of what is called 'safe site' in population biology (Harper 1977).

In the following. I attempt to describe some important characteristics of the establishment niche of Alnus glutinosa in the land uplift area and discuss them briefly against the background of the age structure data:

- soil (and air) moisture. A wellknown requirement for the establishment of Alnus glutinosa seedlings is that the soil surface, as well as the air layer close to it, must stay moist through several weeks around germination (McVean 1955b). The spatial extension of the zone where this requirement is satisfied is given by the characteristic sea water levels. A zone can be distinguished between the level of too long periods of drying out and that of too long periods of inundation (Mäkinen 1964). Under present conditions, it can be seen that this requirement is satisfied on the edge between the herbdominated sea shore vegetation and the woodlands in the land uplift area.

- light. The importance of high light intensities for seedling establishment has been pointed out (McVean 1953, 1955b). Possible zones where this requirement is satisfied include only the open sea shore vegetation and exclude the Alnus glutinosa sites themselves. In the areas studicd here, optimal light conditions occur only outside the Alnus stands in the open sea shore vegetation.

- dispersal. The importance of a seed source close to the point of germination and establishment was stressed by Kujala (1924). McVean (1955b) gave the average wind dispersal range of Alnus glutinosa as $3(-60 \mathrm{~m}$. Almus secds can also be dispersed by running water, where they stay viable over long periods (McVean 1953). 'Wind and wave action concentrate the seed along shore lines, where good water supply and low plant competition give a good chance of establishment' (McVean $1955 \mathrm{~b})$. For the areas studied here, this observation stresses again the favourable conditions at the lower edge of the Almus stands, where surface water flow from the sparsely vegetated surface of the sloping woodlands reaches the herb-dominated sea shore vegetation.

- nitrogen status of the soil. Alnus glutinosa is known as a species often occurring in nitrogen poor habitats, such as road embankments (McVean 1956c) or oligotrophic swamp soils (Fremstad 1983). It has been used during a long time to improve the soil conditions, e.g. through enrichment in nitrogen that is fixed by its root nodules (Akkermans 1971, Dijk 1980). Thus, one major functional role of Alnus glutinosa in the succession on rising sea shores can be seen in the improvement of the nitrogen content of the soil, creating conditions more favourable for other species (see Ugolini (1968) for a review on Almus and its role in soil succession under natural conditions).

The establishment niche of the Alnus glutinosa-populations of the land uplift area is thus created on the emerging sea shores, which at some time after having been lifted above mean water level in favourable years become dry enough to allow establishment of Almus seedlings. These favourable conditions do not occur every year. The discontinuous distribution of establishment locations in Figs 4A-D can probably be explained by the occurrence of unfavourable periods lasting through many years.

To maintain its position in natural woodland communities not affected by such drastic environmental changes as sea shore displacement, Alnus glutinosa relies on a different regenerative strategy. Individuals prolong their life-span considerably through the production of basal shoots that, eventually, take over and replace the dead old stem. Although the age of individual ramets seems to be limited to around 100 ) years of age, the genets of such trees can survive much longer. They then have the typical appearance of a multistemmed $A l$ nus tree. This appearance was common in the Blekinge study area and is interpreted as a consequence of the stable geomorphic conditions. Hence, the establishment niche in the area without land uplift at present is nonexistent, because a population of individuals with steadily rising age is regenerating without significant turnover.

The Alnus glutinosa-trees of exposed shores in the land uplift area can also be multistemmed, but often because basal shoots have developed in response to bark damage caused by ice movements. Then usually, one stem can be recognized to be the main stem.

Acknowledgements - I thank very much Lars Ericson, Umeå, who suggested the basic idea of this study to me. I am also most grateful to Håkan Hytteborn, Uppsala, for supervising and encouraging me as a good friend, and to Eddy van der Maarel. Uppsala, for valuable help. Special thanks go to Ernie de Wildt, Nijmegen, for assistance and companionship during field work. I would also like to thank the staff of the Institute of Ecological Botany, Uppsala University, for help. The manuscript has benefited greatly from criticism by Colin Prentice and Honor Prentice, both Uppsala; I also wish to thank Theo Verwijst for all the discussions we had. The study forms part of the project 'Population dynamics of woody species in primary succession' supported by the Swedish National Science Research Council. I received a scholarship from the German Federal Department of Education and Science through the mediation of the Friedrich-Naumann-foundation. 


\section{References}

Akkermans, A. D. L. 1971. Nitrogen fixation and nodulation of Alrus and Hippophä under natural conditions. - Ph. D. Thesis, Univ. Leiden.

Berglund, B. 1964. The post-glacial shore-displacement in Eastern Blekinge, South-Eastern Sweden. - Sveriges Geol. Unders. Ser. C. No. 599. Stockholm.

Beutel, P. and Schubö. 1983. SPSS 9-Statistik-Programm-System für die Sozialwissenschaften. 4. Aufl. - Gustav Fischer, Stuttgart, New York.

Connell, J. H. and Slatyer, R. O. 1977. Mechanisms of succession in natural communities and their role in community organization. - Am. Nat. 111: 1119-1144.

Cramer, W. 1980. Strandverschiebung und Strandvegetation auf Häverö Prästäng. In: Sjögren, E. (ed.). Studies in plant ecology, dedicated to Hugo Sjörs. - Acta Phytogeographica Suecica 68: 43-50.

- 1981. Die Wechselwirkungen zwischen Strandverschiebung und Strandvegetation - untersucht an einem Beispiel an der Küste von Uppland (Mittel-Schweden). - Medd. Växtbiol. Inst. 1981 (3). Uppsala.

Dijk, C. van. 1980. Ecological aspects of root nodule formation in Alnus glutinosa by Frankia spec. and Penicillium nigricans (Abstract). - Acta Bot. Neerl. 29: 219-220.

DuRietz, G. E. 1947. Wellengrenzen als ökologische Äquivalente der Wasserstandslinien. In: Festskrift tillägnad Prof. Nils von Hofsten. - Zool. Bidr. Uppsala 24: 534-550.

Ericson, L. 1972. Lövvegetation vid norrlandskusten. - Norrlandica VI: 227-255. (In Swedish.)

- 1980. The downward migration of plants on a rising bothnian sea-shore. In: Sjögren, E. (ed.). Studies in Plant Ecology, dedicated to Hugo Sjörs. - Acta Phytogeographica Suecica 68: 61-72.

Fremstad, E. 1983. Role of black alder (Alnus glutinosa) in vegetation dynamics in West Norway. - Nord. J. Bot. 3: 393-410.

Grubb, P. 1977. The maintenance of species richness in plant communities: the importance of the regeneration niche. Biol. Rev. 52: 107-145.

Harper, J. 1977. Population biology of plants. - Academic Press, New York.

Kujala, V. 1924. Die Schwarzerle (Alnus glutinosa (L.) Gaertn.) in Finnland. Pflanzengeographische Untersuchung. - Communicationes ex Instituto Quaestionum Forestalium Finlandiae Editae 7. Helsinki. (In Finnish with summary in German.)

Lid, J. 1974. Norsk og svensk flora. 2 ed. - Det Norske Samlaget, Oslo.

Maarel, E. van der, Cock, N. de and Wildt, E. de 1984. Population dynamics of some major woody species in relation to long-term succession in the dunes of Voorne. - Vegetatio 61: 209-219.

Mäkinen, A. 1964. Observations on the alder growths on formerly water-covered land. - Suo 1964: 16-22. (In Finnish with summary in English.)

McVean, D. N. 1953. Alnus glutinosa (L.) Gaertn. - Biological Flora of the British Isles, No. 1738. - J. Ecol. 41: 447-466.

- 1955a. Ecology of Alnus glurinosa (L.) Gaerin. I. Fruit formation. - J. Ecol. 43: 46-60.

- 1955b. Ecology of Almus glutinosa (L.) Gaertn. II. Seed distribution and germination. - J. Ecol. 43: 61-71.

- 1956a. Ecology of Alnus glutinosa (L.) Gaertn. III. Seedling establishment. - J. Ecol. 44: 195-218.

- 1956b. Ecology of Alnus glurinosa (L.) Gaertn. IV. Root system. - J. Ecol. 44: 219-225.

- 1956c. Ecology of Almus glutinosa (L.) Gaertn. V Notes on some British populations. - J. Ecol. 44: 321-330.

- 1956d. Ecology of Alnus glutinosa (L.) Gaertn. VI. Postglacial history. - J. Ecol. 44: 331-333.

- 1959. Ecology of Alnus glutinosa (L.) Gaertn. VII. Estab. lishment of alder by direct seeding of shallow blanket bog. J. Ecol, 47: 615-618.

Peet, R. K. and Christensen, N. L. 1980. Succession: a population process. - Vegetatio 43: 131-140.

Ruth, R. H. 1968. First-season growth of red alder seedlings under gradients in solar radiation. - In: Trappe et al. (eds). 1968. Biology of alder. Proceedings of a Symposium, held at the Northwest Scientific Association Fortieth Annual Meeting. Pullman, Washington, pp. 99-106.

Schalin, I. 1967. Germination analysis of Alnus incana (L.) Moench and Alnus glutinosa (L.) Gaertn. seeds. - Oikos 18: $253-260$.

- 1968. Germination analysis of grey alder (Alnus incana) and black alder (Alnus glutinosa) seeds. In: Trappe et al. (eds). 1968. Biology of Alder. Proceedings of a Symposium, held at the Northwest Scientific Association Fortieth Annual Meeting. - Pullman, Washington, pp. 107-114.

SMHI, 1976. Vattenstånden vid Sveriges kuster. - Sveriges Meteorologiska och hydrologiska institut. Arsbok 57 (1975) Del 3.2. Norrköping. (In Swedish.)

Trappe, J. M. et al. (eds). 1968. Biology of alder. Proceedings of a Symposium, held at the Northwest Scientific Association Fortieth Annual Meeting. - Pullman, Washington.

Ugolini, F. C. 1968. Soil development and alder invasion in a recently deglaciated area of Glacier Bay, Alaska. - In: Trappe et al. (eds). 1968. Biology of alder. Proceedings of a Symposium, held at the Northwest Scientific Association Fortieth Annual Meeting. Pullman, Washington, pp. 115140 .

Wikström, C. 1966. Isskador på strandträd vid Finska viken. Mem. Soc. Fauna Flora Fennica 42: 5-8. (In Swedish.) 